\title{
Implementation of the remote activities of the Programa Academia da Cidade in times of COVID-19
}

\section{Implantação das atividades remotas do Programa Academia da Cidade em tempos de COVID-19}

\section{AUTHOR'S \\ Gledson da Silva Oliveira ${ }^{1}$ (D) \\ Raquel Bezerra Pajeú ${ }^{1}$ (i) \\ Emmanuelly Correia de Lemos ${ }^{2,3}$ \\ Rafael Miranda Tassitano $0^{4,5}$ (D) \\ Renan Wallacy Yvson dos Santos ${ }^{1}$ (D) \\ Charles Barbosa Gomes da Silva ${ }^{1}$ (i) \\ Danyelle de Cássia Ribeiro de Oliveira ${ }^{1}$ (D) \\ Tatiana Martins Ferraz Holmes ${ }^{1}$ (DD \\ Luiz Eduardo Nunes de Souza ${ }^{1}$ (D) \\ Marcílio Paulo da Silva ${ }^{1}$ (D) \\ Gabriela Maranhão Câmara Campos ${ }^{1}$ (D) \\ Ricardo Augusto Menezes da Silva ${ }^{1}$ (iD \\ 1 Programa Academia da Cidade. Secretaria \\ Municipal de Saúde do Recife, Pernambuco, Brasil. \\ 2 Escola de Governo em Saúde Pública de \\ Pernambuco. Secretaria Estadual de Saúde de \\ Pernambuco, Brasil. \\ 3 Universidade de Pernambuco, Escola Superior de \\ Educação Física, Grupo de Pesquisa em Estilos de \\ Vida e Saúde, Recife, Pernambuco, Brasil. \\ 4 Universidade Federal Rural de Pernambuco, \\ Recife, Pernambuco, Brasil. \\ 5 Programa de Pós-Graduação em Educação Física \\ da, Universidade de Pernambuco/Universidade \\ Federal da Paraíba, Brasil.}

\section{CORRESPONDING}

Gledson da Silva Oliveira

oliveiragledsondasilva@gmail.com

Rua Silveira Lobo n57, apto.302, Ed. Mora-

da de Casa Forte, Recife, Pernambuco, Brasil.

CEP: 52061-030.

DOI

10.12820/rbafs. $25 \mathrm{e} 0158$

\section{(cc) BY}

This work is licensed under a Creative Commons

Attribution 4.0 International License.

\begin{abstract}
Due to the COVID-19 pandemic, the face-to-face interventions of the Academia da Cidade of Recife (PAC-REC) were suspended and a remote activity plan was elaborated. The aim of this study was to describe the implementation and results of remote PAC-REC activities during the COVID-19 pandemic. A quantitative and qualitative analysis was performed based on the PAC-REC online reports and the virtual platforms referring to the remote activities carried out, from April to July 2020. For the implementation of the remote activities, integrated and systematic planning and monitoring meetings among the professionals and the program management were made. The following material was produced: 14 livestreams of bodily practices and physical activities, 10 interviews, 70 videos with different themes, 85 infographics, among others specified by pole. It is concluded that the performance of remote activities of PAC-REC reached its objectives and some should be maintained after the return of face-to-face activities.
\end{abstract}

Keywords: Motor activity; Health promotion; COVID-19; Social media; Remote monitoring.

\section{RESUMO}

Devido à pandemia da COVID-19, as intervençôes presenciais do Programa Academia da Cidade do Recife (PAC-REC) foram suspensas e um plano de atividades remotas foi elaborado. $O$ objetivo deste estudo foi descrever a implantação e os resultados das atividades remotas do PAC-REC durante a pandemia da COVID-19. Foi realizada uma análise quantitativa e qualitativa a partir dos relatórios online do PA$C-R E C$ e das plataformas virtuais referentes às atividades remotas realizadas, dos meses de abril a julho de 2020. Para implantação das atividades remotas foram realizadas reuniôes integradas e sistemáticas de planejamento e monitoramento entre profissionais e gestão do Programa. Foram desenvolvidas 14 lives de práticas corporais e atividade física, 10 entrevistas, produzidos e divulgados 70 vídeos com temas diversos, 85 infográficos, entre outras específicas por polo. Conclui-se que a realização das atividades remotas do PA$C-R E C$ alcançou os seus objetivos e algumas deverão ser mantidas após o retorno das atividades presenciais.

Palavras-chave: Atividade motora; Promoção da saúde; COVID-19; Midias sociais; Monitoramento remoto.

\section{Introduction}

The Programa Academia da Cidade (PAC-REC) created in 2002 in the city of Recife - Pernambuco ${ }^{1}$, comprises the Strategic Policies for Primary Care of the Health
Department (SESAU), being one of the main policies for health promotion and prevention of risks and health problems in the municipality, and, reference for other similar programs in Brazil and other countries². The 42 
physical units, called poles, are present in all municipality, promoting actions of body practices and physical activity (BPPA), health education, among others ${ }^{3}$, which represent an important social mobilization device.

The City Hall of Recife (CHR) following the sanitation protocols for the containment of community transmission of the COVID- $19^{4}$ decreed the suspension of classroom activities in public and private establishments of BPPA, including the PAC-REC 5 .

With the challenge of maintaining its health promotion actions, PAC-REC built its Remote Activities Action Plan during the COVID- $19^{6}$, composed by three axes: the first one of monitoring through virtual reports of the procedures and activities carried out. The second one of administrative, logistics and operational support actions in the territory, in the activities proposed by SESAU, and the third one of core actions of the knowledge of PAC-REC, which referred to the activities that took place at the Program centers faceto-face and that were proposed by this Action Plan to be implemented in the remote format.

Therefore, this article aims to describe the experiences of the implementation of remote activities of PAC-REC during the pandemic of COVID-19.

\section{Methods}

This article is characterized as a descriptive study, an experience report type that addressed the planning, development and the results of remote activities experienced by PAC-REC physical education professionals (PEP) and its managing nucleus (MN), during the $\mathrm{CO}$ VID-19 pandemic. Data from reports that were already part of the monitoring of the Program's actions were used, as well as those created specifically for the remote procedures / activities carried out by the PEP during the suspension of on-site activities at the poles, collected through the Google Forms ${ }^{\circledR}$, as well as the reports from PAC-REC social networks, which were analyzed quantitatively based on the number of profile followers on @ pacrecife and on the number of posts according to data provided by the virtual platform Instagram ${ }^{\circledR}$. In a qualitative analysis, reports of the interactions from users of the 42 program's units and PAC followers accounts on Instagram pointing out the positive or negative aspects of the activities promoted in a virtual way.

Data collection was carried out in the period between April 16 and July 16, 2020. Then, the data were tabulated and analyzed in terms of the number of followers, interactions with the profile and views. The classification of the types of posts in the @ pacrecife was also done by type of practice, methodology, objectives and actors, and observing those which had the greatest number of interactions, in addition to those which could not be saved in the IGTV ${ }^{\circledR}$ of the ${ }^{\circledR}$ pacrecife due to any impediments of the platform itself or other reasons. The details of PAC-REC's remote activities during the COVID-19 pandemic are described in the Logical Model (Box 1).

\section{Results and Discussion}

Initially PAC-REC cooperated in planning, producing and evaluating the Movimenta Recife $\mathrm{App}^{7}$, in partnership with the Secretary for Tourism, Sports and Leisure. Apart from its intersectorial activities and other actions related to supporting tools and services offered by $\mathrm{CHR}, \mathrm{PAC}-\mathrm{REC}$ had to redefine its actions with a focus on the form and intention of material produced in its social networks. In addition, it had to revisit ongoing initiatives regarding the usage and development of actions via virtual platforms such as WhatsApp ${ }^{\circledR}$ groups, Facebook ${ }^{\circledR}$ groups and fanpages attached to PAC-REC itself and to some of its poles.

Two lines of work were created to promote virtual actions according to the workplan. One was conducted by PAC-REC staff, monitored and supported by the $\mathrm{MN}$, with collective and individual actions tailored to the group of users of each operating pole, such as the receptions and active search for videocalls and phonecalls. Through these, staff were able to gather user demands and performed the necessary procedures, at times even forwarding demands to other facilities of the network of healthcare services in Recife.

There were also moments in the virtual classrooms when special attention was given to health and BPPA, as well as sharing of authorial videos with a motivational and educational focus, infographics explaining BPPA plans, videos of recorded lessons, and also live lessons via the platforms of social media.

To a certain extent, it can be said that these remote activities allowed for the preservation of links with users, enabling also the maintenance of BPPA regularity, not to mention extending psychosocial support. We also witnessed the entrance of new users, often following indications from relatives and acquaintances, or forwarded from queries registered at Instagram ${ }^{\circledR}$.

The second line of work was led by the MN in partnership with staff from the Program and from the healthcare network. Starting with a plan to rede- 
Box 1 - Logical Model of PAC-REC remote activities during the COVID-19 pandemic

\begin{tabular}{|c|c|c|c|c|c|}
\hline \multicolumn{6}{|c|}{ Problem: suspension of face-to-face activities at the 42 centers of PAC-REC due to the COVID-19 pander } \\
\hline \multicolumn{6}{|c|}{ Answer to the problem: development of the remote format for the regular activities of the PAC-REC. } \\
\hline \multicolumn{6}{|c|}{ General objective: to promote remotely the regular activities of PAC-REC, using the potential for communication and interaction of virtt } \\
\hline \multicolumn{6}{|c|}{ Target audience: PAC-REC users and the general population with access to the internet and virtual social networks. } \\
\hline Inputs & Component & Objectives & Activities & Products & Results \\
\hline $\begin{array}{l}10 \text { PEP in the MN } \\
155 \text { PEPs of the PAC- } \\
\text { REC } \\
\text { Instagram }{ }^{\circledR} \text { Account } \\
\text { of the PAC-REC } \\
\text { Google Meet }{ }^{\circledR} \\
\text { Account on mobile } \\
\text { phones, computer } \\
\text { and internet networks } \\
\text { belonging to PAC- } \\
\text { REC professionals and } \\
\text { managers } \\
\text { Private Whatsapp } \\
\text { Accounts } \\
\text { Virtual rooms in }^{\circledR} \\
\text { Google Meet }{ }^{\circledR} \text { and } \\
\text { Zoom }^{\circledR}\end{array}$ & Development & $\begin{array}{l} \\
\text { - Maintain health } \\
\text { promotion and disease } \\
\text { prevention actions already } \\
\text { developed by PAC-REC. } \\
\text { - Create and maintain } \\
\text { daily virtual spaces for } \\
\text { the exchange of health } \\
\text { knowledge through the } \\
\text { PAC-REC virtual social } \\
\text { networks. } \\
\text { - Maintain the link } \\
\text { between PAC-REC and } \\
\text { its users through regular } \\
\text { communication with its } \\
\text { professionals. } \\
\text { - Develop intra and } \\
\text { intersectoral activities } \\
\text { in health based on the } \\
\text { interaction with other } \\
\text { professionals and policies } \\
\text { that intersects with } \\
\text { PAC-REC knowledge in } \\
\text { health. } \\
\\
\text { - Improve access to } \\
\text { the virtual means } \\
\text { necessary for PAC-REC } \\
\text { professionals for remote } \\
\text { activities. } \\
\text { - Improve the records of } \\
\text { the activities developed } \\
\text { by PAC-REC. } \\
\end{array}$ & $\begin{array}{l}\text { - MN meetings to evaluate } \\
\text { the actions already developed } \\
\text { and adaptation of the work } \\
\text { processes of the PAC-REC } \\
\text { professionals and managers. } \\
\text { - MN meetings with PAC- } \\
\text { REC professionals, with staff } \\
\text { from the district and central } \\
\text { management levels. } \\
\text { - Study of the social } \\
\text { networks' behavior to define } \\
\text { the strategies for production, } \\
\text { dissemination and regular } \\
\text { dissemination of content. } \\
\text { - Elaboration of the activities } \\
\text { of axis } 3 \text { of the PAC-REC } \\
\text { remote activities plan to } \\
\text { be developed and ways of } \\
\text { monitoring them. } \\
\text { - Weekly meeting to plan } \\
\text { livestreams and daily publi- } \\
\text { cations on social networks. } \\
\text { - Conducting live classes as } \\
\text { livestreams broadcast by @ } \\
\text { pacrecife at Instagram }{ }^{\circledR} \text {. } \\
\text { - Conducting live interviews } \\
\text { with professionals from } \\
\text { different areas of health and } \\
\text { for health education debates. } \\
\text { - Production with groups of } \\
\text { professionals from PCAF } \\
\text { videos, health education and } \\
\text { social mobilization to be } \\
\text { published in @ pacrecife on } \\
\text { Instagram } \\
\text { - Creation and dissemination } \\
\text { of informative graphic } \\
\text { materials aimed at health } \\
\text { promotion and prevention } \\
\text { of risks and injuries and } \\
\text { psychosocial support. } \\
\text { - Mobilization of welcoming } \\
\text { campaigns and creation of } \\
\text { networks of affection and } \\
\text { supported self-care } \\
\text { - Mobilization by the MN, } \\
\text { with municipal management } \\
\text { to proceed with the } \\
\text { distribution process of tablets } \\
\text { and chips for connection } \\
\text { by mobile data, to PAC } \\
\text { professionals and managers. } \\
\text { - Launch of the "PAC-- } \\
\text { Online" website that had } \\
\text { already been created before } \\
\text { this situation. } \\
\text { - Collection, systematization } \\
\text { and analysis of qualitative } \\
\text { and quantitative data from } \\
\text { the Program's internal and } \\
\text { external reports from social } \\
\text { networks. } \\
\text { - Conducting district meetings } \\
\text { between professionals and MN } \\
\text { for the purpose of planning } \\
\text { and evaluating the remote } \\
\text { actions developed }\end{array}$ & $\begin{array}{l} \\
\text { - Weekly MN meetings held. } \\
\text { - Monthly MN meetings } \\
\text { with staff from the district } \\
\text { and central management } \\
\text { levels held. } \\
\text { - Monthly district meetings } \\
\text { of the MN with the } \\
\text { professionals held. } \\
\text { - Studies on social networks } \\
\text { and digital communication } \\
\text { conducted by MN. } \\
\text { - Activities under axis } 3 \\
\text { of the PAC-REC Remote } \\
\text { Activity Plan planned. } \\
\\
\\
\text { - } 14 \text { livestreams of PCAF. } \\
\text { - themed cultural } \\
\text { livestreams to celebrate } \\
\text { festive cycles. } \\
\text { - } 10 \text { interviews conducted in } \\
\text { the form of livestreams with } \\
\text { professionals from different } \\
\text { areas of health. } \\
\text { - } 26 \text { videos of PCAF classes. } \\
\text { - } 44 \text { videos produced } \\
\text { and published on health } \\
\text { education and social } \\
\text { mobilization with } \\
\text { information aimed at health } \\
\text { promotion and prevention of } \\
\text { risks and health problems. } \\
\text { - Production and placement } \\
\text { of } 85 \text { static materials such as } \\
\text { infographics and informative } \\
\text { texts. } \\
\text { - Launch of the "Conta } \\
\text { comigo, conta pra mim" } \\
\text { (Count on me/ Tell me) } \\
\text { campaign of qualified } \\
\text { listening between PEPs and } \\
\text { users. } \\
\text { - Receipt of tablets and chips } \\
\text { for mobile data connection } \\
\text { by all PAC professionals and } \\
\text { managers. } \\
\text { - PAC-Online website } \\
\text { in operation to aggregate } \\
\text { records of all procedures } \\
\text { performed by PAC-REC, } \\
\text { whether in person or remote. } \\
\text { reports by pole and } \\
\text { consolidated of the Program } \\
\text { on the remote activities } \\
\text { developed. } \\
\text { - Monthly district meetings } \\
\text { held. } \\
\text { - Remote activities plan } \\
\text { monitored and systematically } \\
\text { adapted from the evaluation } \\
\text { meetings. }\end{array}$ & $\begin{array}{l}\text { - Maintenance of health } \\
\text { promotion activities } \\
\text { developed by PAC-REC } \\
\text { - Maintenance of links } \\
\text { with PAC-REC users. } \\
\text { - New users join PAC- } \\
\text { REC. } \\
\text { - Expansion of the } \\
\text { activities developed by the } \\
\text { Program. } \\
\text { Greater intra-and } \\
\text { inter-sector integration of } \\
\text { PAC-REC. }\end{array}$ \\
\hline
\end{tabular}

$\mathrm{PEP}=$ physical education professionals; $\mathrm{PAC}-\mathrm{REC}=$ Programa Academia da Cidade $\mathrm{MN}=$ managing nucleus; e-SUS = Rede Eletrônica do Sistema Único de Saúde 
fine the form and content of the @ pacrecife account at Instagram ${ }^{\circledR}$, this line of work aimed to help people stay physically active and also to spread miscellaneous information related to health, leisure, and combating fake news on about COVID-19.

After holding virtual meetings, we defined the working schedule, the amount of partnerships with supporters and invited guests, and the format of the posts. That is include livestreams and videos of BPPA, interviews with health professionals and other specialists, events celebrating holidays, editing and streaming of educational and motivational videos, and static material. In order to accomplish this, it was necessary that the MN understood the functioning of Instagram ${ }^{\circledR}$, regarding its algorithms, tools, privacy rules, as well as information on digital marketing, video editing and image creation ${ }^{8}$.

The PAC-REC contents were posted daily, between $12 \mathrm{~h}$ and $20 \mathrm{~h}$, as this was, according to the report generated by Instagram ${ }^{\circledR}$, the span with the highest traffic of followers. Livestreams were carried out from twice to three times a week, from $16 \mathrm{~h}$ to $17 \mathrm{~h}$, for to create a habit in the audience.

During the studied period, a total of 44 videos were produced and posted. They dealt with health education, social mobilization, and were created by PAC-REC staff; topics addressed ranged from the importance of social distancing, Sars-CoV-2 contagion risks, to the importance of breastfeeding, overall physical and mental wellness, and publicization of virtual events by PAC-REC (Figure 1).

In addition, we also counted a total of 85 educational materials, such as infographics and informative texts. Their topics encompassed: PAC-REC working hours during the pandemic, how to prevent COVID-19 contagion, holidays, incentivizing healthy habits during social isolation, BPPA execution techniques and safety tips, risks related to non-transmittable chronic diseases and sedentarism. Furthermore, a video campaign

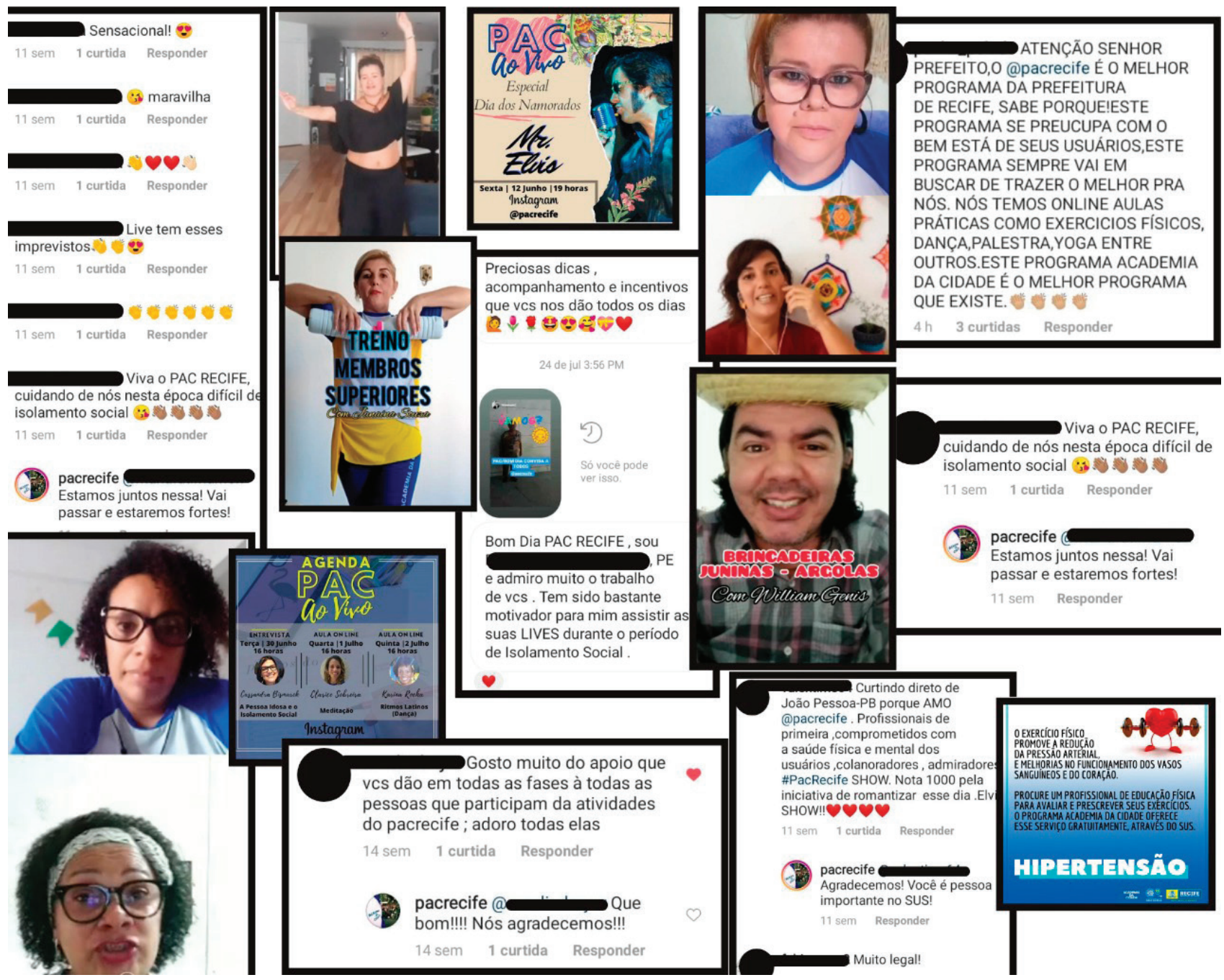

Figure 1 - Illustration of the remote activities developed by PAC-REC during the COVID-19 and users feedbacks 
on social affective themes, 20 static posts dealing with health education, and 26 videos by the BPPA were realized and shared (Figure 2).

As for the livestreams, 14 were carried out by BPPA, five by guest professionals, among them two Brazilians which broadcasted their lessons from their homes abroad (Canada and the US); another with diverse themes, such as family recreation and integrative practices. One of the livestreams also counted with the participation of PAC-REC users, who shared their experiences, testimonials and statements about theirs routines during the social distancing, mediated by a $\mathrm{MN}$ staff member. There was also a livestream with a musical performance in celebration of Valentine's Day (Figure 2).

Following this templated, another 10 livestreams were carried out. They consisted in interviews focused on health education and were performed by PEP from the Program and other guests, i.e. Nutritionists, Psychologists, and Occupational Therapists (Figure 2). The number of visualizations of these educational videos varied between 450 and 1980 for livestreams, and 54 to 222 on simultaneous visualizations.

Aligned with the concept and guidelines of PNPS ${ }^{9}$, PAC-REC elaborated materials with a content which could ensure an integral and expanded care, as well as physical, mental and social wellbeing. The posts dealt with themes such as: precautions on food sanitation, personal hygiene procedures, breathing etiquette, Chinese medicine integrative practices, breastfeeding and exercises, besides gymnastic and dancing lessons.

One of the results of this restructuring was a growth in the number of Instagram ${ }^{\circledR}$ users for PAC-REC: from 1013 to 2344 , a $97 \%$ increase in the first month of implementation of remote activities, reaching a total of 2738 at the end of the studied period, representing a $170 \%$ growth. This enlargement encompassed even individuals who were not users of the Program prior to the pandemic. In addition, according to the reports from the social platform, we observed that, from the new followers, $1 \%$ lived in other Brazilian states; participation of male users was $21 \%$ higher in comparison to face-to-face activities; and the main age bracket of followers was between 35 and 44 years of age, while face-to-face activities were populated mainly by individuals between 39 and 59 years of age ${ }^{10}$.

We also highlight as a positive outcome the receptions via Instagram ${ }^{\circledR}$, which relied on Direct Messaging. Through this tool, users were forwarded to the teams of the pole nearest to their homes, according to the type of demand presented, so that these users could be systematically assisted by Program professionals.

However, it is important to underscore that we also perceived barriers regarding digital inclusion for part of the population. Challenges included: lack of internet access, which according to the Brazilian National Household Survey (Pesquisa Nacional por Amostra de Domicilios Continua, "PNAD Contínua") by Instituo Brasileiro de Geografia e Estatística (IBGE) impacts $25.2 \%$ of the Brazilian population, of which $53.5 \%$ in rural areas and $20.6 \%$ in urban centers; and digital illiteracy, which might have obstructed previous PACREC users in their attempt to access the content published on the social networks ${ }^{11}$.

In order to mitigate this difficulty, users of each pole were instructed by the professionals on the fundamentals of creating an Instagram ${ }^{\circledR}$ 's settings, since to create an account, until how they could navigate this social network. Links from the Instagram ${ }^{\circledR}$ had been shared via WhatsApp ${ }^{\circledR}$ groups. Hence, it was possible to ensure that this content was also disseminated by users who previously had no social media account.

According to data generated by Instagram $^{\circledR}$, the days with the highest increase in the number of followers were Tuesdays, Wednesdays and Thursdays - the same weekdays when livestreams are performed. This pattern points to interactivity as one of the adhesion factors, and corroborates information from the 2019 TIC Domicilios by the Centro Regional para o Desenvolvimento de Estudos sobre a Sociedade da Informação ${ }^{12}$, attached to the Comitê Gestor da Internet no Brasil. According to the latter, $47 \%$ of information queries online deal with health services.

Qualitative results were also gathered. They register impressions and opinions from users concerning the remote activities developed. These reactions were found in post comments, private messages (Direct) - Figure 2. Statements comprise demands on physical, mental and social health, underscoring the importance of integral care for the individual ${ }^{13,14}$, especially when social relations are affected due to social distancing ${ }^{14,15}$. Another outcome was the inclusion of the PAC-REC Instagram ${ }^{\circledR}$ link at the Atende em Casa App, as part of the information brochure of for users of this service as the result of negotiations between the $\mathrm{MN}$ and the team for this app.

Hence, it is possible to conclude that the integrated planning between the management of the MN, PEP and SESAU as well as the systematic procedures to monitor the actions, were fundamental for the imple- 
mentation of the remote activities of PAC-REC in the context of the pandemic COVID-19. It was clear that the use of information and communication technologies and social networks was essential to preserve the Program's actions during social distance. Several positive results ensured: the development of specific activities within each PAC-REC hub; carrying out specific interventions that increased the population's access to the Program; introducing possibilities for future interventions to be promoted in the post-pandemic. Finally, we highlight that it was possible to achieve the objectives outlined in the logical model for remote activities, consequently following the objective of PAC-REC to promote the health of populations.

\section{Conflict of interest statement}

The authors declare no conflict of interest.

\section{Authors' contributions}

Pajeú RB, Silva CHBG and Santos RWY participated in the initial study design, data collection and analysis, writing and critical review of the text. Lemos EC, contributed to the initial study design, data analysis, writing and critical review of the text. Tassitano RM, contributed to the initial study design, data analysis, writing and critical review of the text. Oliveira DCR and Holmes TMF, participated in the initial study design, data collection and analysis, writing and critical review of the text. Souza LEN, Silva MP, Campos GMC and Silva RAM, was responsible for the literature search, data collection and critical text review. All authors approved the final version.

\section{Acknowledgment}

The authors would like to thank the professionals of ACP, the City of Recife.

\section{References}

1. Decreto $n^{o} 19.808$ de 03 de Abril de 2003. Programa Academia da Cidade. [citado em 2020 Julh 11]. Disponível em: http://www.legiscidade.recife.pe.gov.br/decreto/19808/.

2. Cazarin G. Avaliação da contribuição e da sustentabilidade do Programa Academia da Cidade no município do Recife, Pernambuco, Brasil [Tese de Doutorado]. Lisboa: Instituto de Higiene e Medicina Tropical,Universidade Nova de Lisboa; 2019.

3. Pajeú RB, Cavalcanti JRF, Moura VLG, Figueirêdo, CAM, Melo, VMC, Lemos, EC. Interaction between the Family Health Units and the Academia da Cidade Program in Recife, Northeastern Brazil. Revista Brasileira de Atividade Física \& Saúde, 2016:21(5), 410-19.
4. Recife. Decreto no 33.513, de 16 de março de 2020. Dispõe sobre medidas temporárias preventivas a serem adotadas no âmbito da administração pública municipal para enfrentamento da emergência de saúde pública decorrente do novo coronavírus (Covid-19). Diário Oficial Municipal. Recife, PE, Edição 29, 16 mar. 2020.

5. Recife. Decreto no 33.522, de 17 de março de 2020. Dispõe sobre restrições ao funcionamento de equipamentos públicos, sobre suspensão temporária da comprovação anual de vida disciplinada pelo Decreto $\mathrm{n}^{\circ} 32.091$, de 21 de janeiro de 2019, e sobre recomendações restritivas à iniciativa privada no curso da situação de emergência declarada pelo Decreto $\mathrm{n}^{\circ}$ 33.511, de 15 de março de 2020. Diário Oficial Municipal. Recife, PE, Edição Extra, n. 4, 17 mar. 2020.

6. Oliveira DCR, Holmes TMF, Lemos EC, Tassitano RM, Pajeú RB, Oliveira GS, et al. Planning, development, monitoring and evaluation of the Academia da Cidade do Recife action plan during COVID-19. Rev Bras Ativ Fis Saúde. 2020 [citado em 2020 ago 30]. Disponível em: https:// rbafs.org.br/RBAFS/authorDashboard/submission/14372. [Epud ahead of print]

7. Diário de Pernambuco. Com mais de 50 mil usuários, aplicativos do Recife orientam exercícios físicos. [citado em 2020 ago 03]. Disponível em: https://www. diariodepernambuco.com.br/noticia/vidaurbana/2020/07/ com-mais-de-50-mil-usuarios-aplicativos-do-recifeorientam-exercicios.html.

8. Academia do Marketing. Algoritmos do Instagram como funciona. [citado em 2020 ago 04]. Disponível em: https://www.academiadomarketing.com.br/algoritmo-doinstagram-como-funciona/.

9. Brasil. Ministério da Saúde. Gabinete do Ministro. Portaria no 2.446, de 11 de novembro de 2014. Redefine a Política Nacional de Promoção da Saúde (PNPS). Diário Oficial da União, Brasília, DF, Seção 1, 13 nov. 2014.

10. Recife. Programa Academia da Cidade. Formulário de Monitoramento da Avaliações de Aptidão Física e Perfil dos Usuários. Disponível nos arquivos do Programa Academia da Cidade.

11. Agência Brasil. Um em cada 4 brasileiros não têm acesso à internet, mostra pesquisa. [citado em 2020 ago 15] Disponível em: https://agenciabrasil.ebc.com.br/economia/noticia/2020-04/ um-em-cada-quatro-brasileiros-nao-tem-acesso-internet.

12. Agência Brasil. Brasil tem 134 milhões de usuários de internet, aponta pesquisa. [citado 2020 ago 15]. Disponível em: https:// agenciabrasil.ebc.com.br/geral/noticia/2020-05/brasil-tem134-milhoes-de-usuarios-de-internet-aponta-pesquisa.

13. Carnut L. Cuidado, integralidade e atenção primária: articulação essencial para refletir sobre o setor saúde no Brasil. Saúde Debate. 2017;41(115):1177-86.

14. Raiol RA. Praticar exercícios físicos é fundamental para a saúde física e mental durante a Pandemia da COVID-19/ Physical exercise is essential for physical and mental health during the COVID-19 Pandemic. Brazilian Journal of Health Review. 2020;3(2), 2804-13

15. Pereira MD, Oliveira LC, Costa CFT, Bezerra CMO, Pereira MD, Santos CKA, et al. The COVID-19 pandemic, social isolation, consequences on mental health and coping strategies: an integrative review. Research, Society and Development. 2020;9(7):e652974548.

Received: 30/08/2020 Approved: 10/11/2020

Quote this article as:

Oliveira GS, Pajeú RB, Lemos EC, Tassitano RM, Santos RWY, Silva CBG, Oliveira DCR, Holmes TMF, Souza LEN, Silva MP, Campos GMC, Silva RAM. Implementation of the remote activities of the Programa Academia da Cidade in times of COVID-19. Rev Bras Ativ Fis Saúde. 2020;25:e0158. DOI: 10.12820/rbafs.25e0158 